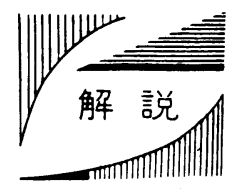

\section{高速ディーゼルエンジンの弁機構 の振動*}

秋 葉 機 四 郎**

\section{1. まえがき}

内燃機関の弁機構は周知のとおり, 吸排気行程の死命 を制する装置であるので，吸排気効率を高めるための方 法が従来の研究の主流である。一方, 弁機構を構成する 部品の摩耗や損傷屯数多く報告されている。なかであ， カム, タペットの摩耗, 弁の損傷はエンジンの設計者を 悩ませる難問である。これらの問題の解決には弁機構の 静的な取扱いでは，不十分な面がある。大形，低速機関 では余り着目されていないが，小形，高速機関では，ジ ヤンプ, バウンスとして知られている跳り現象が弁機構 固有の振動問題として把握され, 幾多の研究が発表され ている。 また, 振動問題を正確に取扱えば, 部品間の動 的応力屯自ら明確になってくるし，摩耗に対する方策も 立てられる。さらに，弁機構に起因する騒音に対してあ 原因の究明, 対策方向は決定できる.

本稿では, 弁機構の振動については, 興味ある問題を 多く有している高速ディーゼル機関を中心に力学的な取 扱い及び応用面について解説を試みる。

\section{OHV機構の力学モデル}

高速機関として, ガソリンエンジンでは OH C 方式を

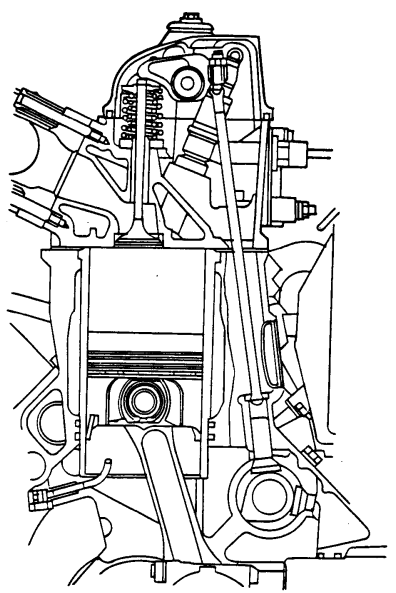

図 $1 \quad \mathrm{OHV}$ 機構の例

\footnotetext{
* 原稿受付 昭和 61 年 11 月 10 日

**正会員 いすぐ自動車懒（川崎市川崎区殿町 3-25-1）
}

構造が単純である，それ故高速性に優ることから採用す るのが常識となってきているが, ディーゼルエンジンで は設計回転速度が比較的低い，製造が容易であることか ら，OHV方式が弁機構の主流を占めている。

図 1 にOHV方式の例を示す。カムとタペットの機構 で, 回転運動から往復運動に変換し, プッシュロッドで 伝達された運動をロッカーアームで転換し，弁に運動を 与えることになる。この運動を弁ばねで制御している。

このことを力学的に説明すると, 弁揚程を与える力ム は加振源であり，運動を伝達するプッシュロッド，口ッ カーアームは剛いばねと見なせる。また，弁は運動する 質量として取扱える。こうした考えに基づき，中西達は 弁機構の力学モデルとして，1質量モデルを提唱した.1)

この先駆的な研究は津田, 酒井らに継承され発展して きた。図 2 は酒井によるモデルを示す．2）弁機構が低速 で通常に運転されている状態では，弁付近を質量 (M 1 ) を中心に解く，1 質量モデルであるが, 弁ばねを $3 \sim 5$ 個の質量とばねに等価に置き換えた集中モデルと連成さ せて解き, 弁ばねのサージングを屯解析できる.ここで, 等価質量 (M 1) には弁ばねの取付荷重が常時力么側の方 向にかかり，弁閉時は弁座の剛性（K２）を縮ませてい る。ジャンプ時およびバウンス時には等価質量の算定を かえて夷際の現象に一致させている。

ロッカーアーム弁側の先端からプッシュロッドを介し てタペットまでの系はモデルではばね $\mathrm{K}_{1}$ と粘性減衰 $\mathrm{C}_{1}$ で表示されているが、夷機での静的な荷重テストの結果 では，荷重の負荷，除荷でヒステリシス現象を示す。し たがって，このばね系は単純に線形ばねと見なした場合 とは隔たりがある。この数式表現には放物線と双曲線と を組み合せて,シミュレートした。

図 3 にはこのモデルの検証のために実施された計算値 と実測值の比較を示す。データには弁機構全体の振動特 性を把握しえるプッシュロッド荷重を採用した。供試エ ンジンの定格回転速度はカ厶軸回転速度で $1400 \mathrm{rpm}$ で あるが, この回転速度までは，振動数，振幅と屯に実測 值と計算値は非常によく一致している。1900 rpmでは, 計算值ではプッシュロッド荷重 0 を示す個所が 2 回ある. この計算ではジャンプを意味しているが, 実験值で屯荷 重 0 の付近で小さな振幅で, 低速回転で見られたより高 い振動数で振動している。2050 rpmではカムノーズを 越える大きなジャンプが発生するが, 弁閉時期に実測で 


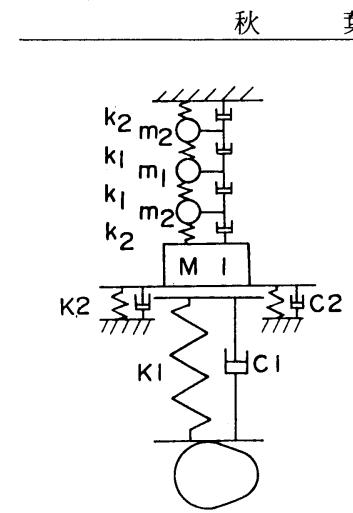

Start

図2 1 質 量 モ デル

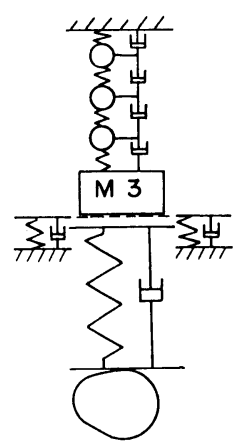

Bounce

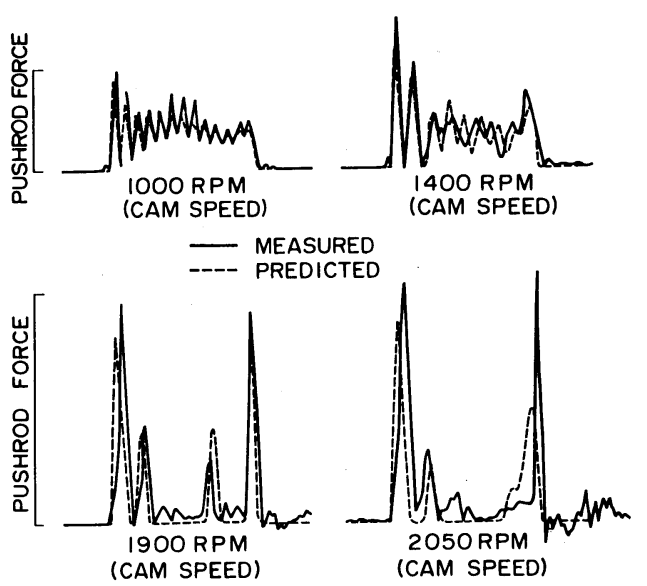

図 31 質量モデルでの実測値と計算値の比較

は高いピークを示し，計算値とかなりの食違いを見せて いる。ジャンプ時には $1900 \mathrm{rpm}$ で述べたのと同様な荷 重変化が見られる。

この結果, このモデルでは, ジャンプのシミュレーシ ョンには現象との不一致が見られるが，設計回転速度以 下では振動現象を十分に記述できるといえよう。

\section{3. ジャンプの発生機構}

弁機構の力学モデルとして，1質量による取扱いでは ジャンプ現象のシミュレーションに不十分が点があるこ とを指摘した。ジャンプは高速での弁開期間中における 等価弁リフトよりの跳躍であることから，エンジンの性 能上には害を及ぼさないが, 信頼性上は部品相互の衝突 をあたらすので好ましくない，さらに，力学的にあ興味 を引く問題であるので, その発生機構を追求した。

\section{1. ジャンプの実験的解析}

ジャンプは弁機構が高速運転時に起す跳躍現象である から，その構成部品の分離を伴なうと考えられる。した がって, どの部品間で接触, 分離が起るかを究明するこ とが, 急務である。

OH V方式の弁機構で運転中に分離する可能性として
は, 弁とロッカーアーム弁側, ロッカーアームプッシュ ロッド側とプッシュロッドロッカーアーム側, プッシュ ロッドタペット側とタペット, タペットとカムの 4 箇所 が考えられる。運転中にこれら部品間の通電性を測定で きれば, 分離, 接触の状態を判定できる。

それには図 4 に示すような弁機構を回線の一部とした 電気回路を利用した. 弁機構を電気的に他の部品から遮 断するためにベークライトブッシュをロッカアームとロ ッカーアームシャフトの間に挿入し, セラミックライナ をシリンダブロックとタペット間にガイドとして挿入し た。また，セラミックピースをプッシュロッド中央部に 挿入して溶接した。この結果, 弁機構は電気的に弁側と カム側に分割されるので二組の回路を使用することにな る. 図 4 に示す電圧 $V_{1} ， V_{2}, V_{3}, V_{4}$ の 4 個を同時 測定すれば，4䇢所の分離，接触の状況を知ることがで きる。

この電気接点法による実験では, 振動の状況を対比す るために弁变位とプッシュロッド荷重屯同時に測定した.

図 5 には供試エンジンの定格回転速度である力ム回転 $1400 \mathrm{rpm}$ での結果を示す.プッシュロッド荷重からは 弁開, 弁閉時期にピークを示すが, ピークの間はかなり 高い王縮荷重を示しており，弁機構の部品間は密着して 回転している。電压経過を見ると, カムのランプ部でプ ッシュロッド, ロッカーアームと弁は接触を始め, 弁閉 時まで接触を続けている。一方, プッシュロッド, タペ ット, カムはラン部で接触か認められるが, 弁開直後, 弁閉直前のプッシュロッド荷重がピークを示す箇所で分 離している波形が見られる。これはカムとタペット間に 油膜が生成していることを意味する。弁開期間の中間域 では油膜厚さが薄くなるので，接触している。.

図 6 には2050 rpmでの結果を示す.プッシュロッド 荷重, 弁変位より判断すると弁開期間中にカムノーズの 前後で 2 回小さなジャンプが発生する. 弁閉時にはバウ ンスが 1 回起る。電圧の測定値からは，プッシュロッド， ロッカーム, 弁は弁開期間中接触したままであるのに対 し, ジャンプに対応する区間ではカムとタペットの分離 


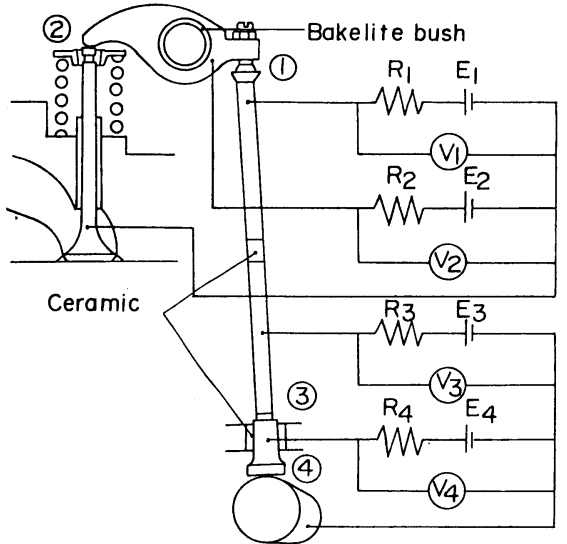

図 4 電 気 接 点 法

$$
\begin{aligned}
& \text { Judgement table } \\
& \text { (1)(2)(3)(4) } V_{1} V_{2} V_{3} V_{4} \\
& \text { on on } O O \\
& \text { on off } E E \\
& \text { off on } E_{1} O \\
& \text { off off } E_{1} E_{2} \\
& \text { on on } O O \\
& \text { on off } \quad E E \\
& \text { off on } E_{3} O \\
& \text { off off } E_{3} E_{4} \\
& \text { here } \\
& E=\left(R_{2} E_{1}+R_{1} E_{2}\right. \\
& /\left(R_{1}+R_{2}\right) \text { etc. }
\end{aligned}
$$

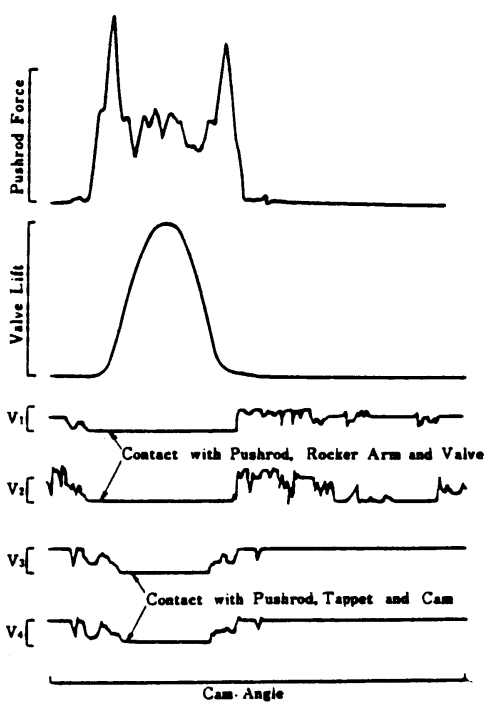

図 5 電気接点法の結果 ( $1400 \mathrm{rpm}$ )

が起きている，また，艻ムとタペットの油膜厚さむ大き くなっている。バウンス時にはすべての箇所で分離，接 触が激しく生じている。 バウンス後の弁閉時も, プッシ ニロッド, ロッカーアーム, 弁は絶えず接触, 分離が続 けられており，カムとタペットには厚い油膜が形成され ている。

実験結果より，ジャンプ時はカムとタペット間で分離 が起り，タペットからプッシュロッド，ロッカーム，弁 までは一体となって運動することがわかった，

\section{2 二質量モデルの提唱}

電気接点法による実験より，弁機構の動的状態におけ る各部品間の挙動が解明された。これ迄の結果より, 跳 躍現象を 1 質量モデルより，実状に近くシミュレーショ ンするための力学モデルを考えるための資料は準備され た。

ジャンプ現象のシミュレーションの問題点を整理する

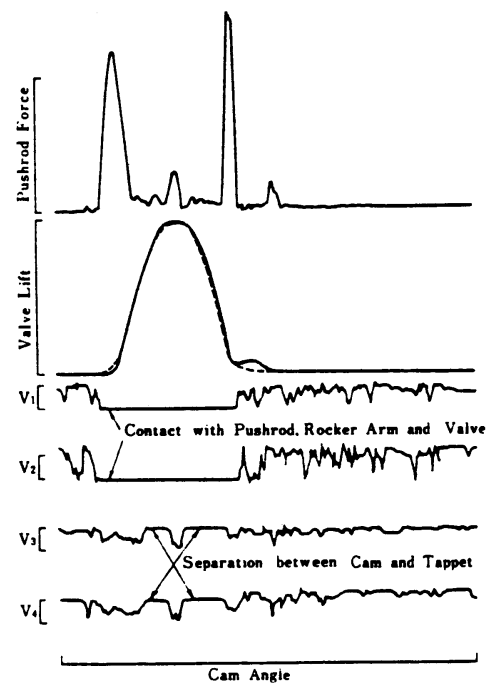

図 6 電気接点法の結果 $(2050 \mathrm{rpm}$ )

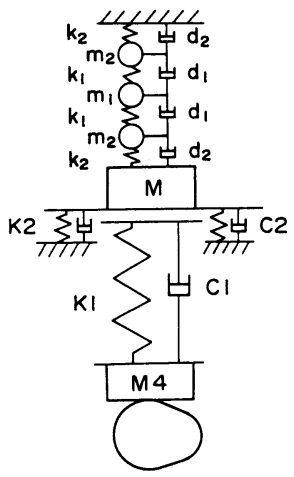

図7 2 質量モデル

と，11.プッシュロッド荷重は０ではなく小さな振幅の 変動荷重が現れる，(2)，弁からタペットまでの部品が一 
体となってカムから離れるの二点である。これらを表現 することができ，かつできるだけ簡潔なモデルとするた めに, 通常運転時は 1 質量モデルでシミュレートし, ジ ヤンプ時はタペット回りの質量を独立した集中質量とし て，運動の自由度を考えた 2 質量モデルを新たに考案し た。図 7 にこのモデル図を示す．

このモデルによると、カムとタペット間に働く接触力 がプッシュロッド系の圧縮力とタペットの慣性力の和と してルンゲクッタの刻み幅ごとに算出される。接触力が 0 または負になると方程式をスイッチ，1 質量モデルか ら2 質量モデルに変える。すおおち, ジャンプ時は M と $\mathrm{M}_{4}$ が一体となって運動するので，(2)の条件を満たす．

ジャンプ時はタペット回りの質量と弁回りの質量の 2 自由度系の振動になるので, 固有振動数は高くなるし, 2 質量間の相対振動による変動荷重を計算するので, (1) の条件を満たす。

2 質量モデルでのプッシュロッド荷重の計算值と実測 值の比較を図 8 に示す。1000 rpm 扰よび $1400 \mathrm{rpm}$ で はジャンプを起していないので 2 質量モデルは 1 質量モ デルと同一の結果を与える。1900 rpm では 1 質量モデ ルでシミュレーションできなかったプッシュロッド荷重 0 近辺での変動荷重が現われるが, 振幅は計算值の方が 大きい. $2050 \mathrm{rpm}$ では, ジャンプ中の振幅に若干の食 違いはあるが, 弁閉時でのピーク荷重は予測值と計算值 はほぼ一致している。これらからジャンプ時の振幅に多 少の不一致は見られるものの，初期の目的を満たした．

\section{4. ヒスダインカム}

弁機構の耐振性を改善するためには，加振源である力 ムの設計に工夫を凝らすことが最良の対策であるとされ， 従来より，力ム設計法の文献屯多い.Dudley が考案 したポリダインカムがカムの設計に初めて動的考盧を採 用した手法として爾来の力ム設計法に大きな影響を与え た. 3) 4) 5)

酒井の 1 質量モデルでは，運動する質量の算定を弁と 弁付近の質量から明確に算出する方法を示した。また, ロッカーアーム弁側先端からカムまでの剛性にヒステリ シスが存在することを站しし，その特性を数式化した。 この手法をDudley 以来のカムの動的設計法に還元し たヒスダインカムである。 ${ }^{6)}$ カムのプロフィル設計に弁 機構の振動の要素を実機により近い形で見込むわけであ るから，異常振動の原因である過渡振動を鎮める働きを するのではないかというのか開発の動機である。

図 9 に対称カムの場合の動的ちちみの経過を示す。こ の曲線は仮定する弁運動の曲線と適用する機関の振動要 素からプッシュロッド系に㗢く力を計算し，ヒステリシ ス曲線上にプロットすることによって描ける。これより カムリフトの動的ちぢみしろに換算し, 弁運動の曲線と の和によってヒスダインカムのプロフィルが設計できる. 弁の運動の曲線には設計上のパラメータの少ないポリ，

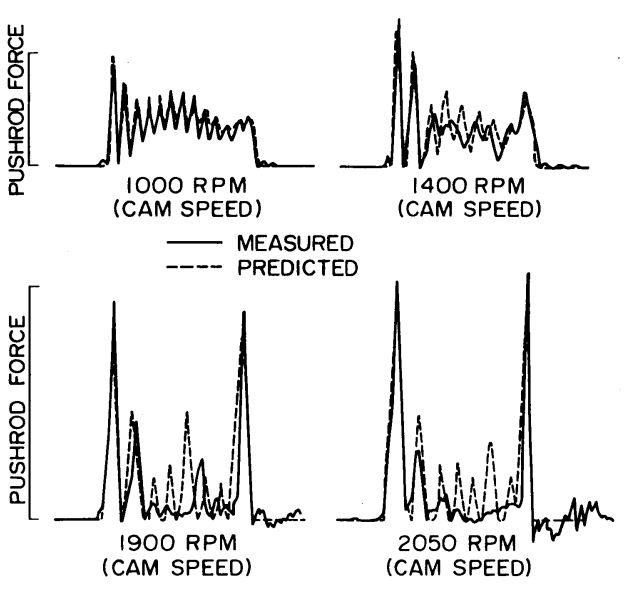

図 8 2 質量モデルでの実測值と計算値の比較

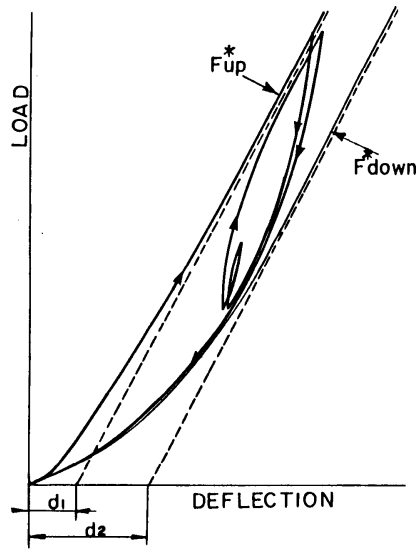

困 9 ヒステリシス特性

ミアル曲線でも，フーリェ 級数を使用した曲線でもかま わない.

図10にポリノミアルカム,フーリエカムとヒスダイン カムの実験結果の一例を示す。バルブギャップをパラメ ータとしたプッシュロッド荷重の変化で,このエンジン での定格回転速度 $1250 \mathrm{rpm}$ (カム軸) である。夷験結 果を要約するとヒスダインは他のカムと比較して振動振 幅が小さい. バルブギャップによる変化による変動が少 ない。

カムの形状は体積効率やピストンとの干涉，熱の影響 等により制約を受けるが，対振性にあ大きく影響を与え るので設計には細心の注意が必要である。

\section{5. 弁摩耗に対応するシミュレーション}

弁機構を構成する部品の中でも弁の摩耗, 特にフェイ ス面の摩耗はその形状がスワールや体積効率というェン ジンの性能に直接結びつくので, 形状変更についての融 

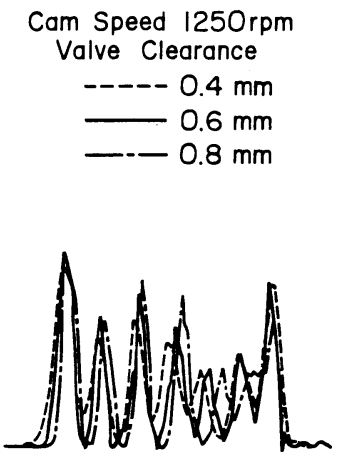

Polynomial Cam

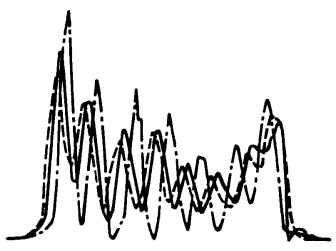

Fourier Cam

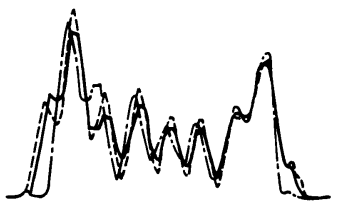

HYSDYNE Cam

図 10 各種力公比較

通性が少なく，その対策が最も困難な部位である。この フェイス面の摩耗に与える影響としては弁の着座衝撃力 が振動の観点からはまず考えつく．ここで着座衝撃力と は弁が着座時に弁座と衝突する際に弁棒 (ステム) には 引張り荷重が作用するが, その荷重のピーク値と定義す る. ${ }^{7)}$

そこで，V型10気筒直噴エンジンを供試エンジンとし て, 着座衝撃力を変化させて, 長時間運転を行ない, 弁 の摩耗量との関係を調査したところ, 図11に示すグラフ がえられた。図11 は着座衝撃力を大きくすれば，弁摩耗 は単調に増加することを示す右上りの曲線である。した がって, 弁の摩耗を低減する時は, 着座衝撃力を小さく することを考えれば良いことになる。

着座衝撃力をシミュレートすることを考えると，ステ ム荷重をカ厶角に応じて算出せねばならないので，2 質 量モデルとは別の次元の新しいシミュレーションモデル を必要とする。

弁を 2 分割してロッカー側とシート側に分れば，振動 方程式を解いた時に，2 質量の相対運動より振動状況を
把握でき，それはステム荷重と等価である．弁の 2 分割 を考えるのは着座衝撃力のシミュレーションという目的 に取って必然であるが, 他の部品の接触応力を求められ るようにしておけば同様の問題に対処できる.

OH V 機構で, このような発想でモデル化を進めると さらに, ロッカーアームの弁側およびプッシュロッド側, プッシュロッドのロッカーアーム側およびタペット側, およびタペットの 7 個の集中質量系が考えられる.また, 弁ばねは酒井の提唱している 3 質量系を踏襲すれば弁機 構全体では10質量, 弁ばねを除けば 7 質量のモデルで必 要条件を満たしたモデルとなる。図 12 に 7 質量モデルの 様式を示す。

この 7 質量モデルの振動方程式は数学的にいえば, カ 么角を独立変数として各質量の変位を徒属変数とする 10 元の連立二階常微分方程式を構成する。これはルンゲク

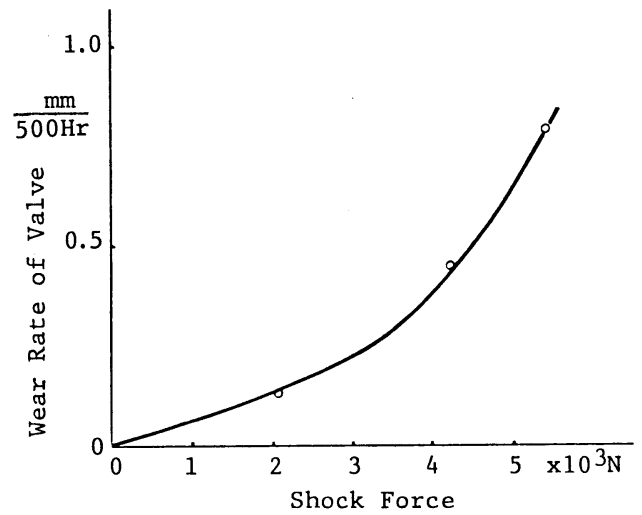

図 11 着座衝撃力と弁摩耗の関係

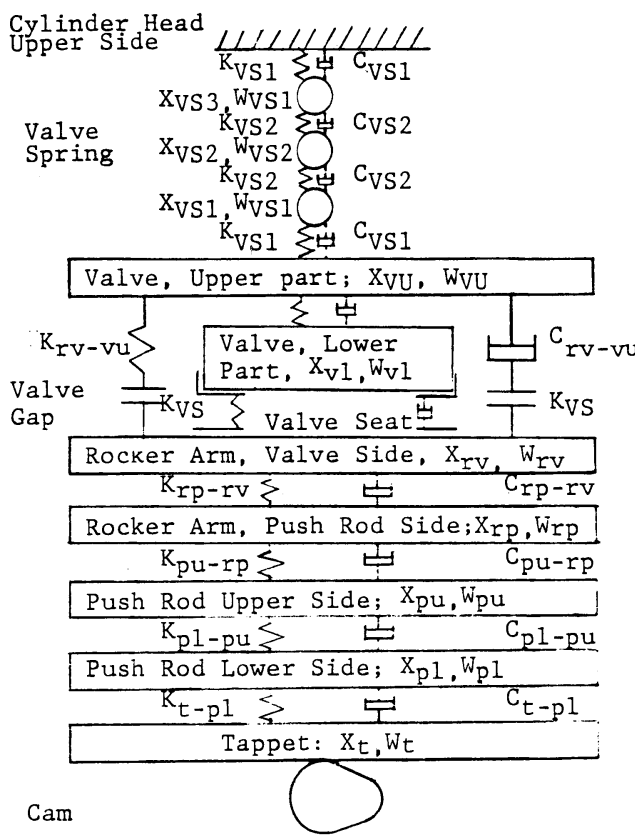

図127質量モデル 
ッターギル法を利用すると数值解がえられるので，コン ピュータープログラムを作成した。

この計算結果と㬰測値の比較を図13に示す.波形を比 較すると, プッシュロッド荷重，ステム荷重共に弁開期 間中に表われる弁機構の固有振動の山の数や高さ, 谷の 深さの対応が取れている. また, 着座衝撃力の発生時期, 荷重の大きさ, さらには荷重の減衰状況屯ほぼ類似の傾 向が見られる。この条件では弁閉時に起るいわゆるサー ジングの影響は実測值では明白には特定できないが, 計 算值からは周期, 振幅の大きさを解析可能である.

このような計算値と実験値の対応より，このモデルを 利用すればプログラムの入力データを変更することによ り，試作品を製作して実験しなくて屯，設計パラメータ の影響を予測できると思われる。

そこで, 設計パラメータとしてまず弁機構の加振源で あり，吸排気効率に大きく影響を与えるカムプロフィル
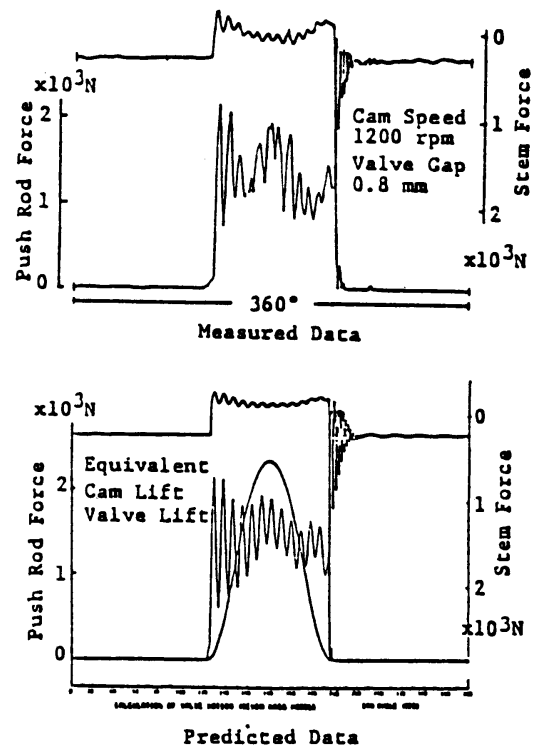

図 137 質量モデルでの結果

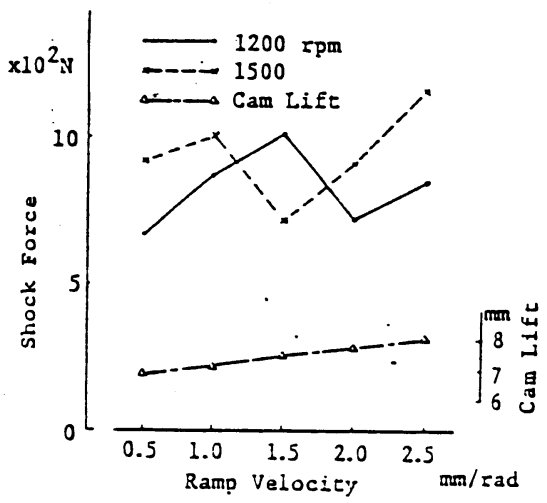

図 14 カムランプ速度の影響

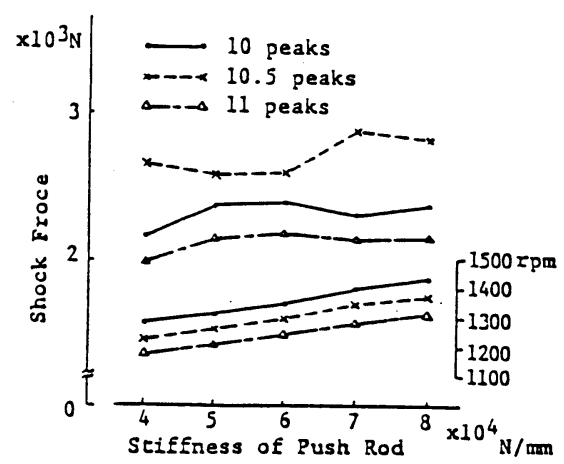

図 15 プッシュロッド剛性の影響

を考えた，従来の常識によると，着座衝撃力は他の条件 を一定とすれば，カムのランプ速度に比例して増加する ことになる。しかし，本計算によると図14に示すように $1200 \mathrm{rpm}$ でも，1500 rpmであ着座衝撃の変化は単調 ではない. 試行した範囲内では，ランプ速度 $1.5 \mathrm{~mm} /$ $\mathrm{rad} 1200 \mathrm{rpm}$ では極大値, $1500 \mathrm{rpm}$ では極小值 を示す。

次に, 弁機構の固有振動に影響を与える要素として容 易に互換が可能な部品であるプッシュロッドを選定して， その剛性だけをパラメータとして変化させた計算を実行 した.図15にその結果を示すが, 図中の $10 ， 10.5$. 11 pea ks は弁開期間中に表われる固有振動の山数であ

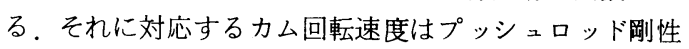
に比例して上昇するがその様子は図中の下部に示した。 着座衝撃力の大きさは $10.5 ， 10 ， 11$ peaks の順に並 んでいる。このように着座衝撃力は回転速度が高い程大 きいとは限らない。この図より, 定速機関では 10.5 peaks のようなピーク值を示す回転速度を避けるか, プッシュロッドの剛性を变えた方がよいとわかる.

本項では弁の着座衝撃力が摩耗との関連が大きく，し かも 7 質量モデルでシミュレーションできることを示し た。予測による結果では, 着座衝撃力は(1)力ムのランプ 速度，(2)プッシュロッド剛性のいずれとも一様な関係を 持たない、また複雑な要因が絡んだ場合は，従来の常識 から予測できないので，新エンジンの計画のみならず， 詳細な最適設計を行う場合もシミュレーションによる予 測を実行することが望まれる。

\section{6. ま と め}

弁機構の振動について, 高速ディーゼルェンジンを例 にとり, 力学モデルについての概説, ジャンプについて の研究, ヒスダインカムの発想と結果を概説した。 また 弁摩耗に対応する 7 質量モデルについてはモデルの概念 から応用法について述べた。

この解説が関係者に何らかの役に立てば幸甚に存じる 次第である。 


\section{文献}

1) 津田, 機械力学, 山海堂 (昭 36 )

2) K. Akiba, A. Shimizu and H. Sakai, SAE 810865 , ( 1981$)$

3) Dudley, SAE Trans, Vol. 12, 19 (1948)
4) Stoddart, Machine Design. Vol. 25, 121 ( J an. 1953) 146 (Feb. 1953 ) 149 (Mar. 1953)

5) Hardiman, etal. SAE 710544 ( 1954 )

6) H. Kanesaka, K. Akiba and H. Sakai SAE 770777 ( 1977 )

7) 秋葉, 清水, 酒井, 機論, 掲載決定 